\title{
Epistemological Analysis of Private Law Themes in the Learn Qur'an Tafsir Application
}

\author{
Nurul Istiqomah ${ }^{1, *}$ Yayuk Whindari ${ }^{2}$ Siti Zulaichah ${ }^{3}$
}

\author{
${ }^{1}$ UIN Maulana Malik Ibrahim Malang, Indonesia \\ ${ }^{2}$ UIN Maulana Malik Ibrahim Malang, Indonesia \\ ${ }^{3}$ UIN Maulana Malik Ibrahim Malang, Indonesia \\ ${ }^{*}$ Corresponding author. Email: istiqomahnurul010@gmail.com
}

\begin{abstract}
Technology is increasingly being used by humans with the aim of making life easier. In a man-made technology, there may be shortages. In this research, the technology to be studied is the Learn Qur'an Tafsir application. The reason why researchers choose this application is because the features in the Learn Qur'an Tafsir cover several themes that use references to the verses of the Qur'an along with their interpretation. Researchers will focus on one of the themes in this application, that is Private Law, which more specific to for the family sustenance law. This theme is important to discuss because sustenance is very crucial in a family. This research is a type of field research. The method used is a qualitative method. Researchers use epistemology to reveal the sources, methods, and validation of the Learn Quran application. The results of this research are first, the source of the Tafsir used is Ibn Katsir's Tafsir, Jalalin's Tafsir, the Indonesian Ministry of Religion's concise \& complete interpretation, Tafsir Al-Azhar and Yusuf Ali Quran Translation from tanzil.net. These commentary books are credible interpretations to be used as references. Second, this application starts with 14 major themes, then divides it into the most specific sub-themes, then includes the verse. There is a repetition of verses with different themes in this application. Discussion of the theme with the steps taken by this application makes the resulting discussion less comprehensive. Third, this application does not provide information about the things that are contained in the verse and an explanation of the theme being researched. Apart from that, the connection between the verses that erase the big theme is also not found in this application. In terms of validity, this application is suitable for beginner users who need a description of the interpretation of the Qur'an on a particular theme.
\end{abstract}

\section{Keywords: Epistemology, Learn Qur'an Tafsir; Private Law, Technology}

\section{INTRODUCTION}

The development of information technology in the era of globalization runs quickly which makes human life easier without losing its humility. This technological development is able to turn challenges into opportunities, and master various methods of problem solving [1]. Technology is increasingly being used by humans. Changing the form of print to digital form is a process. The long process of changing from printed to digital form is interesting to observe because what is being processed is the Koran and its interpretation which are the primary sources of Islamic teachings [2]. In a man-made technology, there may be shortages. In this study, the application to be studied is the Learn Quran Tafsir application. The choice of this application is because the features in Learn Quran Tafsir include several themes that use references to the verses of the Quran along with their interpretation. In this application it is also written that the
Tafsir in Learn Quran Tafsir has been verified by scholars. This application lists the major themes of which there are 14. The themes are further divided into a more specific discussion.

Researchers use epistemology to reveal the sources, methods, and validation of the Learn Quran Tafsir application through thematic descriptions contained in this application. The theme to be examined as a material object is private law that is specific to the discussion of subsistence for the family. This theme is important to discuss because income is very crucial in a family. Problems in the family can arise as a result of understanding and paying a living that is not ideal. Examples of problems that arise are loss of responsibility, affection, love, and divorce.

This research does not discuss in depth about the discussion of income to the family. However, in this discussion, the researcher makes an example to reveal the 
source, method and validation of the Learn Quran Tafsir application. Taking one of these themes is expected to describe the Learn Quran Tafsir application as a whole.

\section{RESEARCH METHODS}

This research is a type of library research (library research). The method used is a qualitative method. According to Bogdan and Taylor in Lexi Moleong, qualitative research is research that intends to understand the phenomenon of what is experienced by research subjects holistically (intact) by means of descriptions in the form of written or spoken words in a special natural context [3].

The theory used in this research is epistemology. Epistemology is a branch of philosophy that studies knowledge.[4] Epistemology tries to answer about how we get knowledge, what are the sources of knowledge? What is the nature, scope and scope of knowledge? Is it possible for humans to get knowledge? Until the stage of knowledge that humans might catch [5]. The use of epistemological theory in this study is useful for revealing the sources, methods, and validity of the Learn Quran Tafsir application [6].

The primary data used in this study are the interpretive books contained in the Learn Quran Tafsir application. The second data is secondary data taken from photos, books, articles, magazines, and other relevant data. The data that the researchers got from the discussion of livelihood for families in the theme of Private Law were analyzed using epistemological theory. The sources, methods, and validity of the Learn Quran Tafsir application will be examined through this theme.

\section{DISCUSSION OF MATERIAL}

\subsection{Learn Quran Tafsir (LQ Tafsir) Application}

Learn Quran Tafsir (LQ Tafsir) offers technology solutions to make it easier to understand the interpretation of the Quran through search engine technology with reliable and accountable Quran interpretation content. This application was developed in July 2017 in the form of a website (tafsir.learn-quran.co) and an Android mobile application (bit.ly/GetLQTafsir) with basic features as well as marketing with a very minimal budget since launching in January 2018. In within 3 months since its launch, it was recorded that more than 800,000 users have accessed the site and used Learn Quran Tafsir and strongly support the continued development of this product. Now, LQ Tafsir has a total of 800,000 site visitors / users with an average of $>1600$ daily users, with a record 117 thousand people using the Learn Quran Tafsir application for one week [7]. The development team of Learn Quran Tafsir is 1. Sani as the supervisor, 2. Denny as the Head of the Foundation, 3. Himma as Quality Assurance, 4. Angga as AI / NLP Engineer, 5. Irfan as Mobile Developer, 6. Asma as
Fundraiser, 7 . Aji as technology advisor, 8. Fajri as content advisor, 9. Salamah as Business Analyst, 10. Mardadi as Full-Stack Web Developer, 11. Defani as Graphic Designer, 12. Nur as Associate Product manager, 13. Jihan as Associate Product manager, 14. Diani as Fundraising manager, 15. Danu as Business Analyst Intern, 16. Azhim as Fundraiser, 17. Ayyash as intern vidiographer, 18. Risman as intern vidiographer, 19. Majid as Software Engineer, 29. Luthfi as Software Enginer, 21. Afkar as Software Engineer, and 22. Arief as Quality Assurance.

The Learn Quran Tafsir application is an application and website to learn to understand the Koran correctly, easily, quickly and for free. This smartphone can be accessed via the Playstore and Appstore or even opened directly through the website page. Learn quran tafsir is a development application of the learn qur'an application and website. The Learn Quran Tafsir application consists of 5 interpretations in 2 languages. Tafseer and language in Learn Quran Tafsir will continue to grow along with the development of this application. Besides being able to help understand the Alquran with its tafsir feature, this application also provides various other features, namely Search and Read Tafseer. has a small ram which is only $2.2 \mathrm{mb}$. In addition, this application is also available on a website that is very easy to access, all you have to do is search and learn quran tafsir or type the link https://tafsir.learn-quran.co/id then you will be taken directly to the main menu on the application.

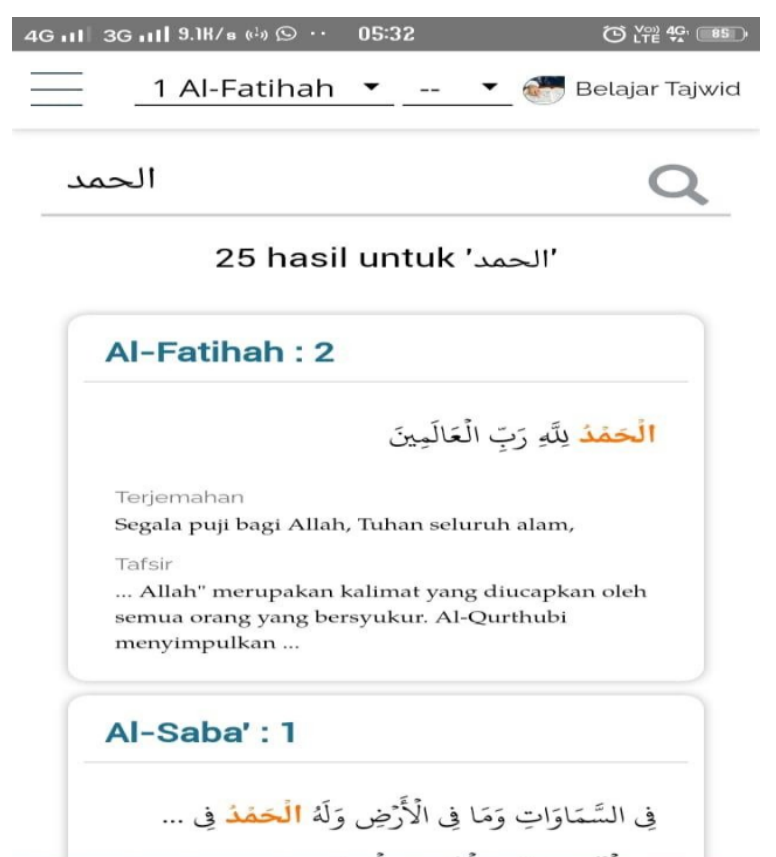

Figure 1. Menu to find al-Qur'an verses from Lafadz pieces 


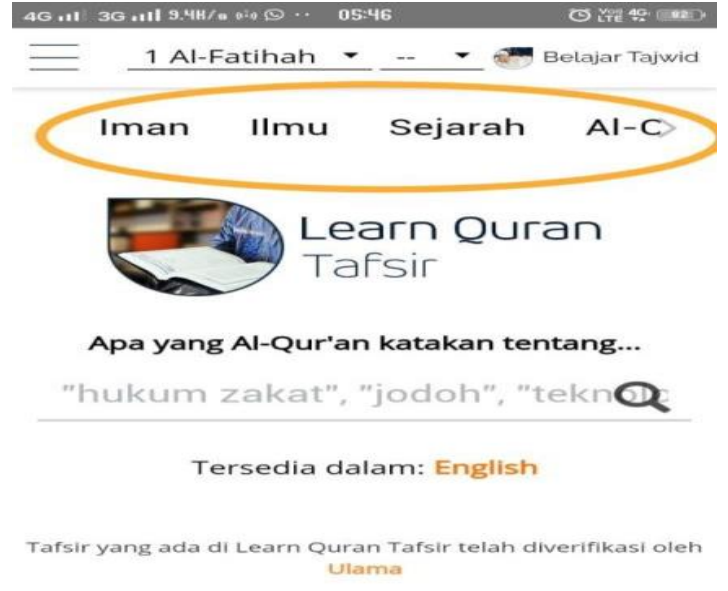

Figure 2. The themes in the Learn Qur'an Tafsir Application

\subsubsection{Private Law in the Learn Quran Tafsir Application}

The theme of private law is one of the themes in Learn Quran Tafsir. Apart from the theme of private law, there are several more themes listed in Learn Quran Tafsir. These themes are Faith, Knowledge, Past Nations, History, Al-Quran, Morals and Adab, Worship, Food and Drinks, Clothing and Jewelry, Muamalat, Judiciary and Judges, Criminal Law (Jinayah), and Jihad [8].

The income for the family has 3 sections of discussion, namely the commandment to provide for the family, the person who is most entitled to be provided with a living, and simple in providing a living.

\section{EPISTEMOLOGICAL ANALYSIS OF PRIVATE LAW THEMES}

In this study, the focus discussed is the sub-theme of livelihood for families. The discussion about subsistence for the family is further divided into 3 more detailed discussions, namely the first commandment to provide for the family contained in Q.S. Al-Baqarah: 177. Second is the person who is most entitled to provide a living contained in Q.S. Al-Baqarah: 177. The third is simple in providing a living which is contained in Q.S. Al-Baqarah: 233.

In Islam, it is the husband's responsibility to fulfill the basic needs of the family. The fulfillment of a living is part of the effort to maintain the integrity and existence of a family. The obligation to provide for the husband occurs since the marriage contract is carried out [9].

Discussion on the command to provide for the family in Q.S. Al-Baqarah 177 has the following meaning

"Virtue does not turn your face to the east and to the west, but virtue is the (virtue) of people who believe in Allah, the Last Day, angels, books, and prophets and give their loved ones to relatives, orphans., poor people, people who are traveling (travelers), beggars, and to free my slave, who pray and pay zakat, people who keep promises when promised, and people who are patient in neediness, suffering and in times of war. These are the ones who are righteous, and they are the ones who are righteous."[8]

The interpretation of Ibn Kathir in this application explains in general the contents of the verse. The content of the content in accordance with the discussion of the command for subsistence lies in a sign that someone's devotion is to give wealth to the family. The discussion about the person most entitled to be provided with a living also uses the same verse, Al-Baqarah 177. The content of the verses that correspond to this discussion is the priority of the people who are given a living. The order is family, orphans, poor people, travelers, beggars and slaves.

The discussion about simple in providing a living contained in Q.S. Al-Baqarah: 233 whose translation is as follows:

"And mothers should breastfeed their children for two full years, for those who want to breastfeed completely. And it is the father's duty to bear their livelihoods and clothing in a proper manner. A person is not burdened more than he can afford. Neither a mother must suffer for her child nor a father (suffer) because of her child. Heirs are also (obliged) like that too. If the two of them want to wean with agreement and deliberation between the two, then there is no sin on both of them. And if you want to feed your child to someone else, then there is no sin for you to pay properly. Fear Allah and know that Allah is All-Seeing what you are doing [8].

In the Al-Azhar Tafsir, it is explained that the father has the obligation to provide food and clothing to the divorced mother in exchange for breastfeeding the child $m a^{\prime} r u f$. The meaning of ma'ruf here is according to its ability.

Each discussion is displayed one Verse and its translation. In the discussion of family support, there is one verse that is the same for two discussions. After describing the verse and the translation, this application offers 5 interpretations of Ibn Katsir's Tafsir, Jalalin's Tafsir, the Indonesian Ministry of Religion's concise \& complete interpretation (Lajnah Pentashihan Al-Quran Mushaf, Research and Training Agency of the Ministry of Religion of the Republic of Indonesia), and Al-Azhar Tafsir. Users of this application can easily copy data from verses, translations, and interpretations that are included.

References or sources of Tafsir used in Learn Quran Tafsir are Ibnu Katsir Tafsir, Jalalin Tafsir, the Indonesian Ministry of Religion's concise \& complete 
interpretation (Lajnah Pentashihan Al-Quran Mushaf, Research and Training Agency of the Ministry of Religion of the Republic of Indonesia), and Tafsir AlAzhar. The English translation that is used as a reference is Yusuf Ali Quran Translation from tanzil.net [8]. These commentary books are credible interpretations to be used as references.

Ibn Kathir's Tafsir is a book of commentaries that appeared in the Middle Ages. Judging from the rukukan, this interpretation is included in the tafsir bil ma'tsur. Ibn Kathir was very selective in choosing authentic narrations. The Indonesian Ministry of Religion's Interpretation is compiled based on the dynamics of society and the development of science and technology at that time. Society needs a practical and easy to understand interpretation. This interpretation is a milestone in the spirit of interpreting the contextual alQur'an. While the Al-Azhar Tafsir has an adabi ijtima'i style with the beauty of the Malay language which is presented based on the social context of its time. The language technique used is a variety of language styles that are commonly used everyday, making it easier for readers to understand the interpretation, the majority of which are Indonesian citizens [10].

In this application it is written that the interpretations in Learn Quran Tafsir have been verified by scholars. The scholar in question is Nur Fajri Romadhon, Lc. He is a recitation of Al-Qur'an who has expertise in the field of al-Qur'an recitation, Tafsir, and Islamic law. He is the founder of the BISA Learning Center and is a fatwa commissioner in the Tarjih \& Tajdid Muhammadiyah Council in Depok City. In Learn Qur'an Tafsir he does not only fill in the content but also acts as a narrator in the Learn Qur'an Tajwid application [8].

In including interpretations, this application does not provide information on the pages of the book, the printed book, and the publisher used. Moreover, in the book Tafsir Jalalain and Tafsir Ibn Kathir which are included is the Indonesian version. Thus it should be necessary to provide reference information for the translated book used, so that the translator and version of the book used should be known.

The method used by this application is thematic. There are 14 themes discussed in this application, one of which is private law. The themes discussed will be further divided into several sub-themes to the details of the most specific themes. For each of the most specific discussions, one verse is included in accordance with the theme. Apart from verses, there are also translations and interpretations taken from the 5 books.

In connection with the thematic method, AlFarmawi has arranged stages in the practice of thematic interpretation. These stages are 1) Determining the topic or theme to be discussed. 2) Collecting verses that concern 3) Arranging the order of the verses according to the period of their descent 4) Understanding the correlation between verses 5) Paying attention to the asbab nuzul to understand the context of the verse 6) Completing the discussion with hadiths and the opinions of scholars 7) Studying the verses in depth 8) Analyze the verses completely and comprehensively by compromising between the 'am and the specific, mutlaq, muqayyad. 9) Make conclusions from the issues discussed [11].

When referring to the thematic interpretation theory promoted by Al-Farmawi, this application still has not carried out the perfect stages as above. First, this application starts with 14 major themes, then divides it into the most specific sub-themes, then includes the verse. These steps are different from al-Farmawi, which first collects verses that are in line with the discussion expected by the researcher. This makes it possible to repeat verses with different themes in this application. Because in one verse several different subjects are found. Discussion of the theme with the steps taken by this application makes the resulting discussion less comprehensive.

Second, this application does not provide information about the things that are contained in the verse and an explanation of the theme being researched. This application only includes verses, translations, and interpretations of the 5 commentaries. Other explanations to explain such a theme from the hadith are also not found. Apart from that, the connection between the verses that erase the big theme is also not found in this application. This makes each verse describing the sub-theme to the most specific stand on its own, making it difficult to find a comprehensive explanation.

Regarding the validity of this application, researchers refer to the sources and methods used. The sources used in this application are books of credible interpretations. The thematic method used, according to the researcher, has not yet presented comprehensive information. Thus, this application is suitable for novice users who need a description of the interpretation of the Koran on a particular theme. This application makes it very easy for users who want to find verses and descriptions of certain themes listed in this application. However, the interpretations that are obtained are still divided according to the sub-themes specified in this application. As for users who want to find a more indepth look for a comprehensive concept of the Koran and Tafsir on a theme, they still need other application tools that provide a more complete book and the steps initiated by Al-Farmawi.

\section{CONTRIBUTION OF KNOWLEDGE}

The Learn Quran Tafsir (LQ Tafsir) application offers technology solutions to make it easy to get information from the Quranic interpretation. This application is a search engine technology that includes thematic interpretations of the Quran. This application was created by a development team of 22 and verified by Nur Fajri Romadhon, Lc. 
After conducting an epistemological analysis of the theme of private law, the researchers came to several conclusions. With regard to sources, this application uses references from Ibn Katsir's Tafsir, Jalalin's Tafsir, the Indonesian Ministry of Religion's concise \& complete Tafsir (Lajnah Pentashihan Al-Quran Mushaf, Research and Training Agency of the Ministry of Religion of the Republic of Indonesia), and Tafsir AlAzhar. These books are interpreted books that have good credibility. The English translation uses the Yusuf Ali Quran translation from tanzil.net.

As for the method, the method used by this application is thematic. There are 14 themes discussed in this application, one of which is private law. The themes discussed will be further divided into several sub-themes to the most specific details of the discussion. For each of the most specific discussions, one verse is included in accordance with the theme. Apart from verses, there are also translations and interpretations taken from the 5 books. The drawback is, this application does not include the page, publisher, or translation used. Each specific discussion is only given one verse and interpretation without being given information on the relevance of the verse or the content of the verse that matches the theme. This makes the discussion less comprehensive.

Meanwhile, the validity of this application, after looking at the sources and methods used, the researcher concludes that this application is suitable for users who want to know the verses, translations, and brief interpretations that are separated in certain themes. But for users who want to get a more comprehensive description of a particular theme, they can look at other applications.

\section{CONCLUSION}

The Learn Quran Tafsir (LQ Tafsir) application offers technology solutions to make it easy to get information from the Quranic interpretation. This application is a search engine technology that includes thematic interpretations of the Quran. This application was created by a development team of 22 and verified by Nur Fajri Romadhon, Lc.

After conducting an epistemological analysis of the theme of private law, the researchers came to several conclusions. With regard to sources, this application uses references from Ibn Katsir's Tafsir, Jalalin's Tafsir, the Indonesian Ministry of Religion's concise \& complete Tafsir (Lajnah Pentashihan Al-Quran Mushaf, Research and Training Agency of the Ministry of Religion of the Republic of Indonesia), and Tafsir AlAzhar. These books are interpreted books that have good credibility. The English translation uses the Yusuf Ali Quran translation from tanzil.net.

As for the method, the method used by this application is thematic. There are 14 themes discussed in this application, one of which is private law. The themes discussed will be further divided into several sub-themes to the most specific details of the discussion. For each of the most specific discussions, one verse is included in accordance with the theme. Apart from verses, there are also translations and interpretations taken from the 5 books. The drawback is, this application does not include the page, publisher, or translation used. Each specific discussion is only given one verse and interpretation without being given information on the relevance of the verse or the content of the verse that matches the theme. This makes the discussion less comprehensive.

Meanwhile, the validity of this application, after looking at the sources and methods used, the researcher concludes that this application is suitable for users who want to know the verses, translations, and brief interpretations that are separated in certain themes. But for users who want to get a more comprehensive description of a particular theme, they can look at other applications.

\section{REFERENCES}

[1] M. A. Nugroho, "Pemanfaatan Teknologi Informasi dalam Peningkatan Mutu Pendidikan Islam di Madrasah", Mudarrisa Jurnal Kajian Pendidikan Islam, 6 (1) (2014), 30-60. DOI: https://doi.org/10.18326/mdr.v6i1.30-60.

[2] A. Fatakh, "Nafkah Rumah Tangga Dalam Perspektif Hukum Islam”, INKLUSIF, 3(1) (2018) 57-74. DOI: 10.24235/inklusif.v3i1.2766

[3] L. J. Moleong, Metode Penelitian Kualitatif, Bandung: Remaja Rosdakarya, 2009

[4] M. Lathif, Orientasi Ke Arah Pemahaman Filsafat Ilmu, Jakarta: Prenadamedia Group, 2014

[5] J. S. Suriasumantri, Filsafat Ilmu Sebuah Pengantar Populer, Jakarta: Pustaka Sinar Harapan, 2017.

[6] H. Aliyah, "Epistemologi Tafsir Syu'bah Asa", Hermeneutik, 9(2) (2015) 364.

[7] D. Yusuf, Learn Quran Tafsir: Aplikasi Tafsir Quran Terlengkap dengan Artificial Intelligence in Kompasiana, 2019, retrieved form https://www.kompasiana.com/dennyyusuf2325/5 ce511dc3ba7f7598d08d592/learn-quran-tafsiraplikasi-tafsir-quran-terlengkap-denganartificial-intelligence

\section{[8] https://tafsir.learn-quran.co/}

[9] J. Nelli, "Analisis Tentang Kewajiban Nafkah Keluarga Dalam pemberlakuakn Harta Bersama", Al-Istinbath: Jurnal Hukum Islam, 2(1) (2017) 29-46. DOI: 10.29240/jhi.v2i1.195 
[10] A. Alviyah, "Metode Penafsiran Buya Hamka Dalam Tafsir Al-Azhar", Ilmu Ushuluddin, 15(1) (2016), 25-35. DOI: http://dx.doi.org/10.18592/jiu.v15i1.1063

[11] A. A. al-Farmawi, "Metode Tafsir Maudu'i, terj. A. Jamrah", Jakarta: Raja Grafindo Persada: 1996 